\title{
Insights on Foreign Direct Investments, and the Transfer of Technology and Knowledge from Nordics to Baltics
}

\author{
Aurelija Burinskiene $^{1}$, Arunas Burinskas ${ }^{2}$ \\ ${ }^{1}$ Vilnius Gediminas Technical University, Business Management Faculty, \\ Sauletekio al. 11, LT-10223 Vilnius, Lithuania \\ ${ }^{2}$ Vilnius University, Faculty of Economics and Business Administration, Sauletekio \\ al. 9, LT-10222 Vilnius, Lithuania \\ Iaurelija.burinskiene@vilniustech.lt; ${ }^{2}$ arunas.burinskas@evaf.vu.lt
}

\begin{abstract}
The article discusses foreign direct investment, the transfer of technology and knowledge from Nordics to Baltics. In today's world, both the importance of foreign direct investments, and the transfer of technology and knowledge are growing constantly. FDI means the raise of capital together ensuring the development of region. Investors have the freedom for choice and are focusing on the increasing returns from investments. Article complexly assesses the impact of foreign direct investment, technology and knowledge transfer. The purpose of the paper - to assess impact of FDI to country competitiveness and the transfer of technology and knowledge and carry out comparative analysis between countries. Several methods were used in the article as follows: the review of scientific papers and the analysis of statistics.
\end{abstract}

Keywords: Technology, knowledge transfer, FDI, Nordic countries, Baltic countries. 


\section{Introduction}

Three Baltic countries have great similar geographic location, territorial size and structure of economy, the development patterns and demography. However, there are several differences, especially towards Estonia, reaching competitiveness among other Baltic countries. Indeed, there does seem to be an integrated Baltic economy. Estonia attracts investments for international development; Latvia is aware from regional spillover effects; Lithuania has no influencing driver (Poissonnier, 2017). The shorter the distance is between countries the higher FDI foreseen among countries. As Nordic countries are the leaders in innovation, it important to analyse which countries are impacted from such investments.

After the revision of scientific papers published by world famous publishers such as Oxford Cambridge and Harvard University Press Houses, Routledge, Springer Science, M.E. Sharpe, and other the authors identified that 12 thousand publications are focusing on FDI, technology transfer, knowledge transfer, 198 books mention the Nordic countries and 3 of them - Baltic countries.

This shows that such topic get less attention among researchers who presented publications to FDI, technology transfer, knowledge transfer. Most of them are analyzing the impact, but it is not associated with inter-countries links.

The research tasks are defined as follow: 1) the topic is disclosed under theoretical level, 2) research results provide insights on the inter-country links under the topic.

The empirical research follows the analysis of countries and their data benchmark. The scientific novelty of the study - presented the overview which highlights the practical investigations on FDI, technology transfer, knowledge transfer which is happening between Nordic and Baltic countries.

The material presented could be important for researchers, which analyze the inter-country issues related to FDI, technology transfer, knowledge transfer.

\section{Foreign Direct Investments}

In the modern world affected by globalization, foreign direct investment attracts particular attention from both scientists and international institutions. Foreign direct investments and options to attract them among researchers is a rather debatable issue and therefore the generally accepted definition about foreign direct investment is not accepted (Fons-Rosen et al., 2021, 2018). Foreign direct investment as investments attracted to gain a interest on return from entities performing operations in another than investor country. FDI is treated as investments across borders, which are carried out by entities of a single economy with a view to gaining a longterm interest (Amdam et al., 2007).

The importance of investment has grown rapidly. FDI is related to continued country development and increasing productivity, especially in expanding markets (Harms et al., 2019). The conditions of globalization give investors a wide margin 
of choice as to where to invest their funds, while traditional policies to promote FDI focus on the increase of investments. Investment isn't directly attracting the capital but influences technology, science, knowledge, human capital and the region (Amoroso et al., 2018). It also promotes the growth of competitiveness (Alfaro et al., 2009). Competitiveness is treated as the ability to create conditions for certain economic, social, political, institutional, infrastructural and other ones that are necessary for region grow and well-being population aspects. Foreign direct investments create long-term and stable links among various economies and promote the transfer of knowledge and technology, and give for FDI inward reaching country possibility to present goods and services internationally (Baldwin et al., 2014). Foreign direct investments are the funding source and can be an important development tool in a favorable policy environment (Ha et al., 2016). Foreign direct investments by other authors are treated as funds allocated by investors to companies (Venkataramany et al., 2010). Alternatively, they present FDI as allocation of investments from country to country, by creating links among countries, reflecting also objectives of domestic economy seeking for long-term investigations into enterprise and getting significant shareholder voice in the corporate governance case (Smeets, 2008). Long-term orientation is manifested in activities of creator, investor and direct investment entity of the enterprise and has a fundamental impact on business management.

Lithuanian authors interpret foreign investment as embedded (invested) capital intended development of activities, which from foreign countries which take place over time (Herger et al., 2016). Understanding the impact of foreign direct investment on the production of beneficiary country got lot of debate among researchers and policymakers. The attraction of foreign direct investments are becoming important as the country has to be presented in international communication (Bombarda, 2013). This means that foreign investments affect the management of the company. Knowledge and technological novelty help to improve learning, opportunity to potentially increase productivity, help to transform the enterprise structure, and stimulate economic activity. Scientists state that foreign direct investments have the greatest evidence manifested in the growth of GDP (Borsos et al., 1995). The economic environment of each of the countries must be created and shaped to attract FDI (Arnold et al., 2009). Attraction of FDI is highlighted and plays a crucial role in the national development strategy in many countries, seeing the growth of economy and encompassing technology and knowledge transfer (Hunya, 2004; Irandoust, 2016).

\section{Technology Transfer}

Technology transfer is the driver for economic growth of countries. Appropriate economic policies should therefore focus on improving the facilitation of processes across the countries and the flows of information and technology between key 
players such as innovators, businesses, governmental and financial organizations.

Countries with transition economies are in special case. The Baltic States saw a sharp decline in GDP, resulting in a general reduction in competitiveness and a widening technology gap between Western Europe countries. This might pose some difficulties in view of the process of European integration in the Union and the specific circumstances surrounding it, such as the liberalization of international trade and manufacturing flows between Member States (e.g., capital, labor and technology) (Newman et al., 2015). The transfer of technology is process that is complex and covers elements of technology, which are embodied or not embodied (such as components / machinery, licenses, etc.), also, knowledge (which is called the behavior of organization). The transfer of technology is parallel with innovations, embodying later on technology-related knowledge about products and services.

Technology transfer is treated as the flow between the owner / owner of the technology and the buyer / user of the technology (Ismail et al., 2018). This allows you to bridge the access gap to a specific technology in a variety of ways: by purchasing, lending, renting, and/or franchising. Technology commercialization is related to technology transfer; which focus on the practical use of research and development efforts.

The extent of the diffusion of technology transfer has to follow the existing technological infrastructure - for example technical-scientific resources, potential of research and industry development activities, the start-ups of technologies and the financing system for technology transfer, instruments for promoting cultural innovations in country, the extent of the openness of the country towards other countries, competition and industrial cooperation (initially mainly the channels of transnational corporations). Economic indicator is one factor that determines technology intensity.

Indeed, the variety of factors related to the involvement of the labor force will strongly correlate with the flows of technology transfer.

\section{Knowledge Transfer}

Knowledge - the key unit of organizations, as knowledge allows to develop key competencies and allows companies to withstand problems, deal with complexity and reach competitiveness. Thus, researches focus on the transfer of knowledge and its uptake. The difference attracting attention tells that knowledge has clear form or implicit one. Additional aspects studied by scientists include the processes of learning, knowledge creation and transfer. The transfer of knowledge can be treated as process and during it branches share experience among them (Ismail et al., 2018). Although the transfer of knowledge, it management and learning phases were recognized, the application in business is still lacking. Relationship between the transfer of knowledge in a customer-vendor relationship, the duration of the 
relationship. In addition, cooperative relationships with customers and suppliers generate new knowledge. The authors identified that the transfer of knowledge and the culture of its development presents the increase of enterprises performance indicators. In addition, although an exhausted study on knowledge management concludes that the benefits of learning can arise from integration and cooperation, most studies have not indicated that this aspect is directly.

The company's knowledge-based approach, which indicates that companies should be analyzed on the basis of their knowledge resources, was considered to be the most appropriate because of its ability to explain whether companies existed effectively. Knowledge is thus a form of information and know-how, and the ability of a company to generate and transfer this knowledge can give a competitive advantage. It should be noted that knowledge needs to be developed in this regard and this requires appropriate processes. However, not every process can provide valuable knowledge, so the principles of knowledge creation can provide unique resources.

Below is the presentation of empirical research results, which summarize the inter-country revision related to FDI, technology transfer, knowledge transfer.

\section{Empirical Research}

The empirical research results are presented after the revision of statistical data collected by The World Bank (2021), Eurostat (2021), UNCTAD (2021), Cornell University (2021), INSEAD (2021), United Nations (2021), The World Intellectual Property Organization (2021), and OECD (2021).

The authors start the analysis from GDP numbers, then move to FDI and the examples of technologies and patents numbers, and intellectual assets. First of all, we see that Estonia, Latvia and Lithuania has the huge economy recession in 2009 comparing with effect in Euro area. At the same time, we see that GDP per capita is much lower in Baltic countries than in Euro zone, but Estonia is a bit forward than other Baltic countries.

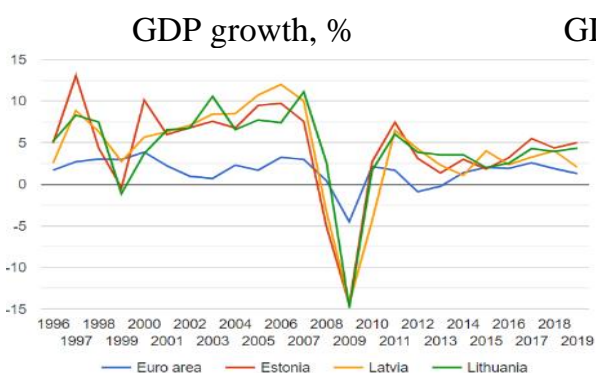

GDP per capita, PPP USD
GDP per capita, in constant 2010 USD amounts

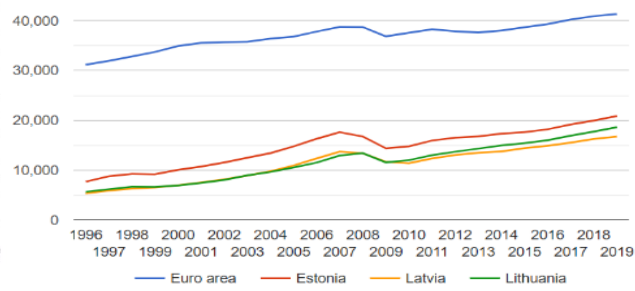

GDP per hour worked in current USD, PPP adjusted 

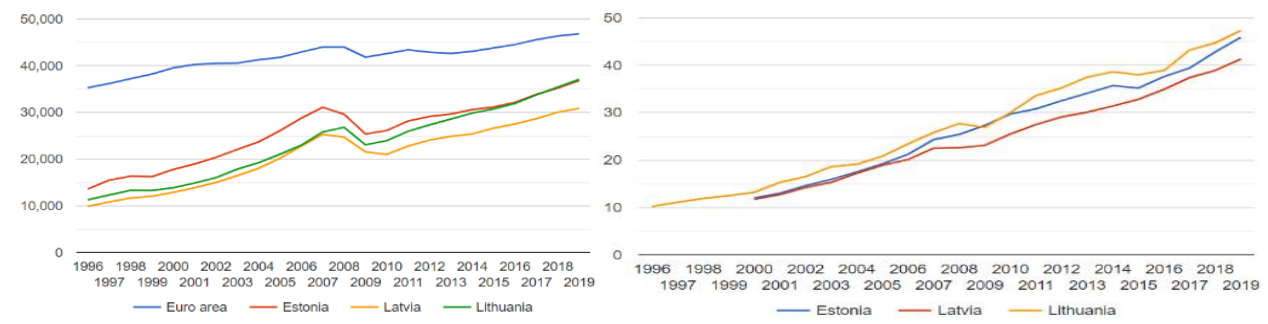

Fig. 1: Compared GDP, its growth and productivity in the Baltics (Source: The World Bank, 2021; OECD, 2021).

Following the number of GPD per capita, in purchasing power parity (PPP) case, we see that Latvia is lagging and Lithuania is catching Estonia. However, the grow in Euro area is becoming slower after 2010. The GDP per hour worked for PPP adjusted, the Lithuania is slight frontier, but talking about general trend - it is constantly growing.

GDP growth in Baltics and Nordics is almost similar in Figure 2 (a part). In Figure 2 (b part) from Nordics, current account as a percentage of GDP is the highest in Norway and Denmark, which jumped over the Sweden. However, the trend in Finland is declining after 2001.

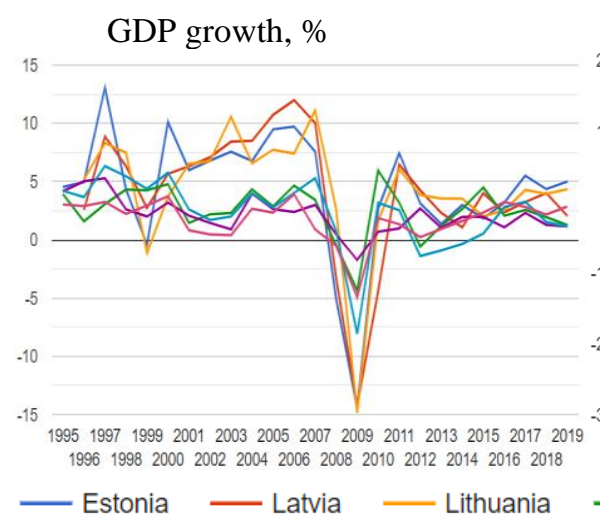

(a)

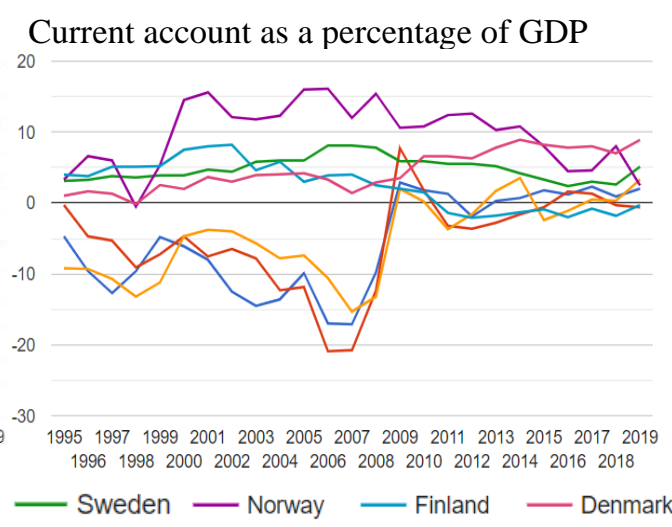

(b)

Fig. 2: The comparison of current account as a percentage of GDP and GDP growth in Baltics and Nordic (Source: The World Bank, 2021).

In GDP per capita, the highest-level shows Norway, when goes Denmark, Sweden and Finland in the row. In GDP per capita as PPP case, the sequence of countries stays the same. And finally, GDP per hour worked in current PPP adjusted, the Norway is ahead, and Denmark jump over Sweden numbers in recent years.

GDP per capita, constant 2010 USD GDP per capita, PPP USD GDP per hour worked in current USD, PPP adjusted 

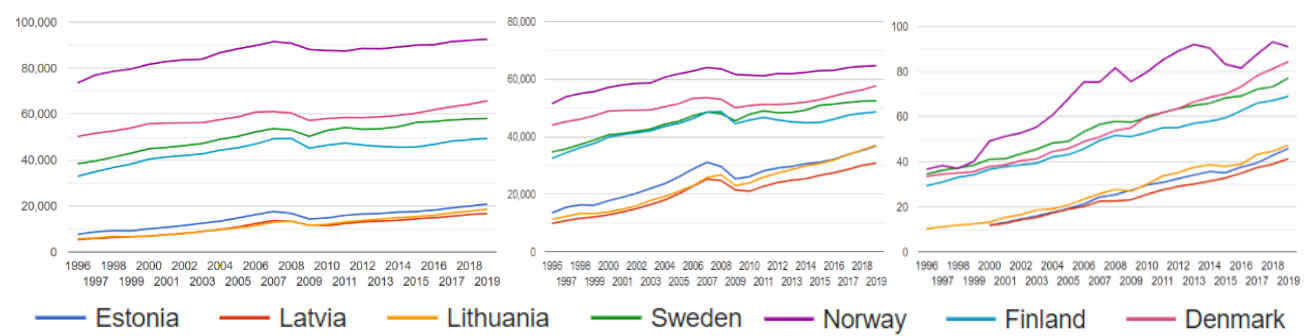

Fig. 3: Comparison of GDP and productivity: Baltics with Nordics

By comparing exports and imports volumes with GDP in percentage, we see that Estonia is the leader, except in 2019 when Lithuania numbers caught-up Estonia and jumper over Estonia numbers. From Nordics, Norway has the lowest numbers and in some years Finland as well.

Imports of products and services as percentage of GDP

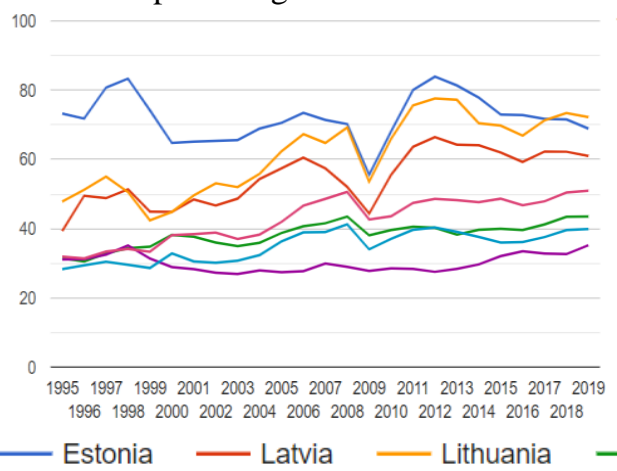

Exports of products and services as percentage of GDP

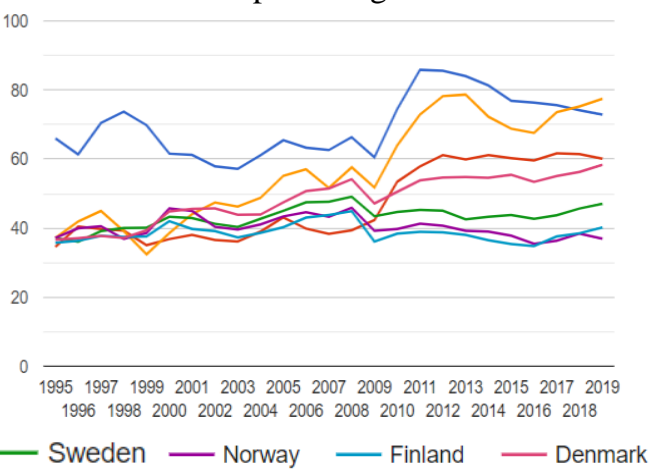

Fig. 4: The comparison of exports and imports in Baltic and Nordic countries (Source: The World Bank, 2021).

FDI numbers per full-time employee shows that Sweden has the highest FDI inwards in both countries: Estonia and Lithuania. The average inward from Nordic was the highest to Estonia comparing to other Baltic countries and to total FDI inwards.

FDI per full-time employee (Eur)

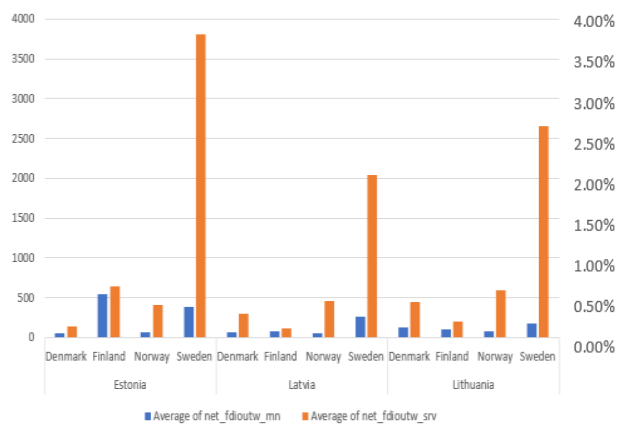

Total inward FDI versus FDI from Nordic, as a percentage of GDP

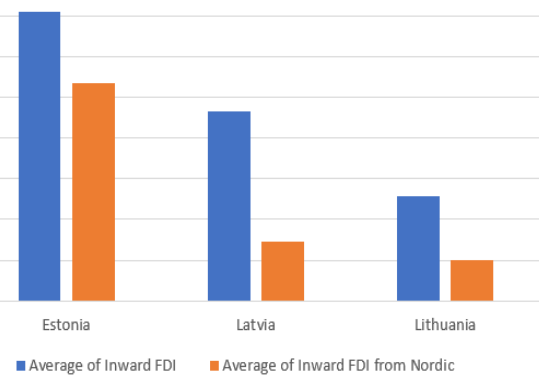


Fig. 5: FDI to Baltic countries from Nordics and its share from total FDI (Source: Eurostat, 2021 and UNCTAD, 2021).

The highest return of FDI inwards in sectors of production and services was the highest in Lithuania for Finland FDI inwards and in Estonia for Denmark FDI inwards. The only negative case, is in Latvia for Finland FDI inwards.

FDI, margins and labor productivity based on FDI inwards chart shows that average labor productivity is the highest in Latvia and follows the Norway FDI inwards. The highest margins are in Lithuania for Sweden FDI inwards. And the highest investment is in Latvia from Norway.

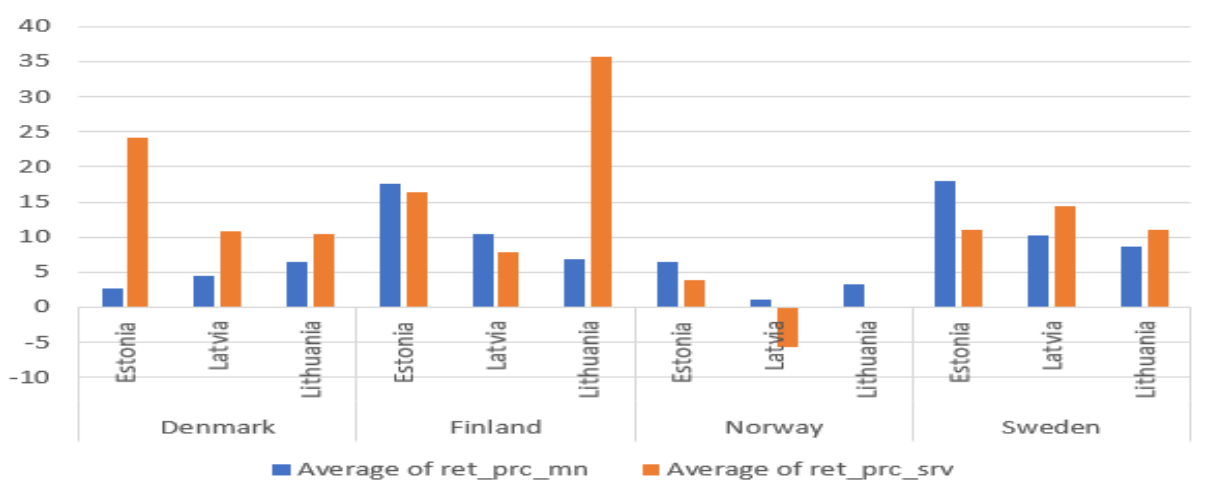

Fig. 6: FDI return in percentage in production and service sectors according to FDI inwards (Source: Eurostat, 2021).

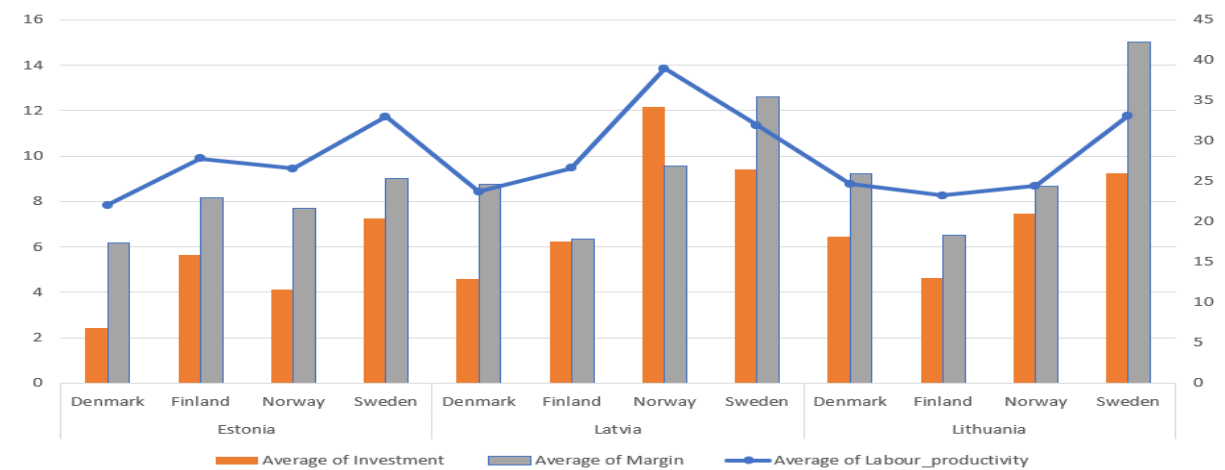

Fig. 7: FDI, margins and labor productivity by full-time employee based on FDI inwards (Source: Burinskas et al. 2021; Eurostat 2021).

The highest innovation index is for Sweden and Finland. However, Lithuania is lagging behind other countries. In recent years the highest numbers of R\&D activity from GDP is in Sweden; however, Denmark has the lowest numbers in this category. 


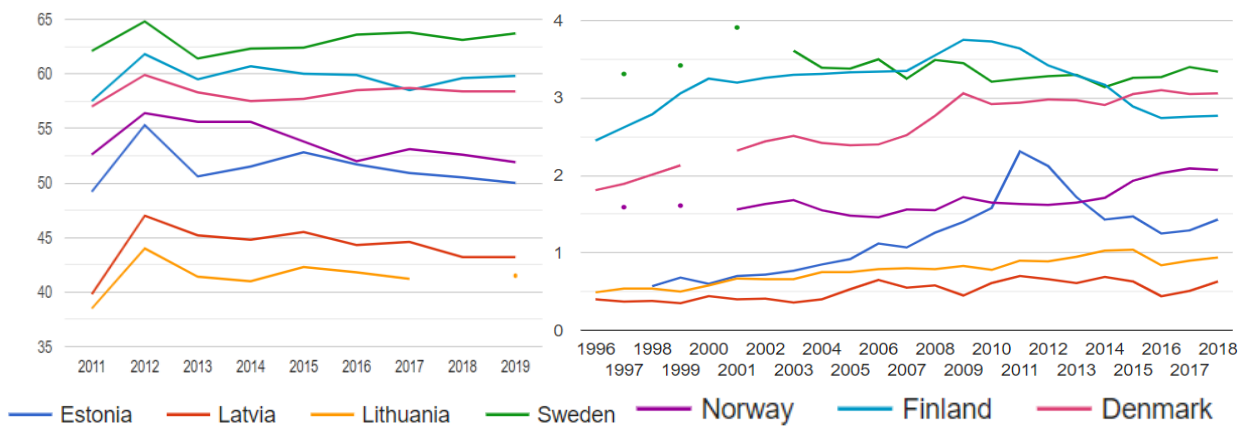

Fig. 8: The comparison of innovativeness and $R \& D$ expenditure as a percentage of GDP

(Source: Cornell University, 2021; INSEAD, 2021; The World Intellectual Property organization, 2021; the United Nations, 2021).

The highest numbers in IT exports are in Estonia and Latvia which was overtaking position in recent years from Estonia. The high-tech exports were in Norway; however, the Finland lost the top position from 2016. The application of patents by residents is the highest in Sweden but the trend is declining from 2001.

IT exports, $\%$ of total goods exports

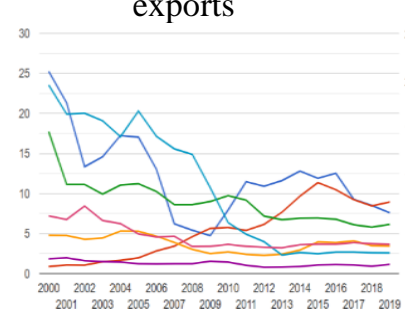

— Estonia — Latvia
High tech exports, \% of manufactured exports

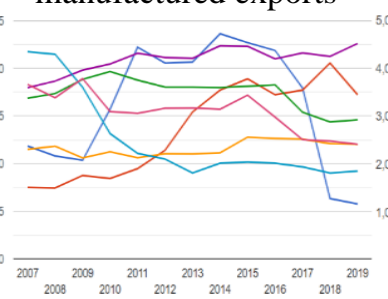

Lithuania
Patent applications by residents

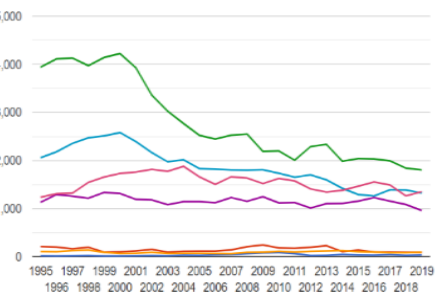

Norway

Finland - Denmark

Fig. 9: IT \& High-tech exports (Source: the United Nations, 2021; The World Intellectual Property Organization, 2021).

The revision of statistical data shows that the innovativeness and patents' applications have quite strong positions in Sweden.

By attracting intellectual assets, Estonia is leading from Baltic countries. The intellectual assets are attracted through Nordic FDI inwards, which also means the knowledge transfer to a country, such as Estonia. 


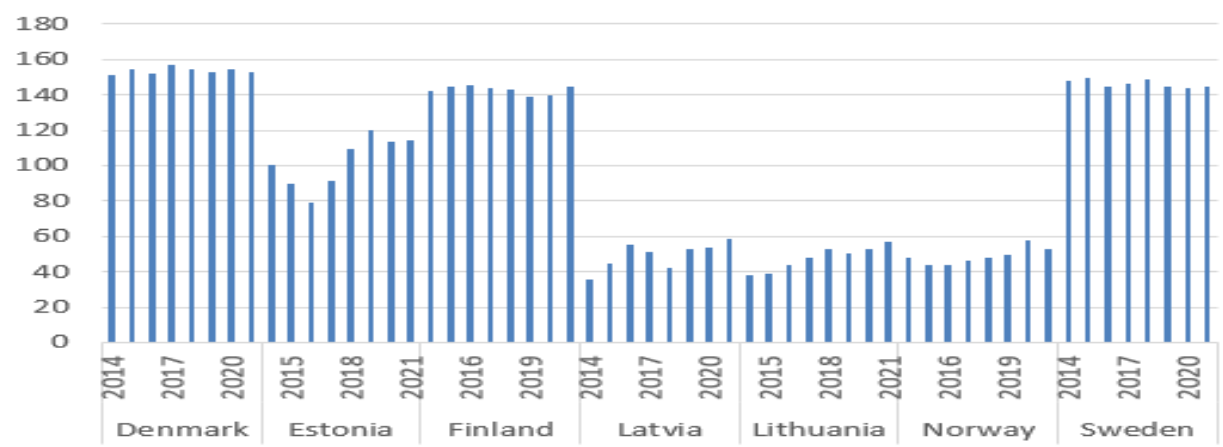

Fig. 10: Intellectual assets (relative to the EU in 2014) (Source: Burinskas et al. 2021;

Eurostat, 2021).

The analysis shows which countries are getting competitive advantage from FDI inwards, technology and knowledge transfer.

\section{Conclusions}

The analysis of the scientific literature review shows the importance of investigations on FDI and its impact and the transfer of technology and knowledge from Nordics to the Baltics.

In revised scientific literature, the authors indicated interpretations that explain phenomena of technology transfer helping to reach advantage in costs towards national production. Therefore, in high R\&D industries, trade frictions limit possibilities of technology transfer mostly. Such gives advantages for the domination of multi-national companies in the development of international trade.

The ability of enterprises to produce and export technologies, including IT and high-tech, gives the country competitive advantage.

The results of the study show that Sweden is dominating among Nordic countries and, Estonia has higher competitive position in attracting FDI inwards among Baltic countries. Estonia has the highest IT export and getting intellectual assets; it is also leading in imports and exports of products and services volumes measured as per cent of GDP. Such maybe explained in a way that Estonia has the highest Nordic FDI inwards than other Baltic countries.

It is noted that constructed empirical research could be repeated for comparison of other Eurozone countries.

\section{References}

Amdam, R. P., Lunnan, R., \& Ramanauskas, G. (2007). FDI and the transformation from industry to service society in emerging economies: A Lithuanian-Nordic perspective. Inžinerinè ekonomika, 1, 22-28. 
Alfaro, L., \& Charlton, A. (2009). Intra-industry foreign direct investment. American Economic Review, 99, 2096-2119.

Amoroso, S., \& Müller, B. (2018). The short-run effects of knowledge intensive greenfield FDI on new domestic entry. The Journal of Technology Transfer, 43(3), 815-836.

Arnold, J. and B. Javorcik (2009), 'Gifted Kids or Pushy Parents? Foreign Direct Investment and Plant Productivity in Indonesia', Journal of International Economics, 79, 1, 42-53.

Baldwin, R., \& Okubo, T. (2014). Networked FDI: Sales and sourcing patterns of Japanese foreign affiliates. The World Economy, 37(8), 1051-1080.

Bombarda, P. (2013). Extensive and Intensive Margins of Export and FDI: the Role of Wages. WP Fondazione Masi, 15.

Borsos, J., \& Erkkilä, M. (1995). Foreign Direct Investment and Trade Flows between the Nordic Countries and The Baltic States (No. 540). ETLA Discussion Papers.

Burinskas, A.; Rasmus, B. H.; Tvaronavičienè, M.; Šimelytė, A.; Razminienė, K (2021). FDI, technology \& knowledge transfer from Nordic to Baltic countries. Insights into Regional Development. 3 (3), 31-55.

Cornell University (2021). Innovation, Entrepreneurship, and Technology. $<$ https://business.cornell.edu/faculty-research/themes/innovation-entrepreneurshipand-technology/>

Eurostat (2021). Foreign direct investment - rates of return. $<$ https://ec.europa.eu/eurostat/statistics

explained/index.php?title=Foreign_direct_investment_-_rates_of_return>

Fons-Rosen, C., S. Kalemli-Ozcan, B.E. Sørensen, C.Villegas-Sanchez, and V. Volosovych (2018). Foreign investment and domestic productivity: identifying knowledge spillovers and competition effects. Paper presented at the 4th Mainz Workshop on FDI and Multinational Firms. Available as NBER Working Paper 23643. <https://www.nber.org/papers/w23643>.

Fons-Rosen, C., Kalemli-Ozcan, S., Sørensen, B. E., Villegas-Sanchez, C., \& Volosovych, V. (2021). Quantifying productivity gains from foreign investment. Journal of International Economics, 131, 103456. 
Ha, B., \& Kang, K. C. (2016). FDI and the Two Margins of International Trade: Evidence from Korea. Journal of International Trade \& Commerce, 12(6), 169-185.

Harms, P., \& Wacker, K. M. (2019). The special issue on FDI and multinational corporations: an introduction. Economics, 13(1).

Herger, N., Kotsogiannis, C., \& McCorriston, S. (2016). Multiple taxes and alternative forms of FDI: evidence from cross-border acquisitions. International Tax and Public Finance, 23(1), 82-113.

Hunya, G. (2004). FDI in small countries: the Baltic States (No. 307). Research Report.

The World Intellectual Property Organization. Intellectual property statistics. Intellectual Property Statistics (wipo.int)

Irandoust, M. (2016). Structural changes, FDI, and economic growth: evidence from the Baltic states. Journal of Economic Structures, 5(1), 1-9.

INSEAD (2021). Strategic R\&D management. <https://www.insead.edu/executiveeducation/research-development-operations-management/strategic-researchdevelopment-management>

Ismail, M., Hamzah, S. R. A., \& Bebenroth, R. (2018). Differentiating knowledge transfer and technology transfer. European Journal of Training and Development.

Newman, C., Rand, J., Talbot, T., \& Tarp, F. (2015). Technology transfers, foreign investment and productivity spillovers. European Economic Review, 76, 168-187.

OECD (2021). OECD data. Productivity - GDP per hour worked - OECD Data.

Poissonnier, A. (2017). The Baltics: three countries, one economy? (No. 024). Directorate General Economic and Financial Affairs (DG ECFIN), European Commission.

Smeets, R. (2008). Collecting the pieces of the FDI knowledge spillovers puzzle. The World Bank Research Observer, 23(2), 107-138.

UNCTAD (2021). Foreign direct investments. <https://unctadstat.unctad.org/wds/> . United Nations (2021). Trade exports. <https://unstats.un.org/unsd/trade/>. 
Venkataramany, S., \& Miller, S. T. (2010). Future Prospects For Foreign Investment In Lithuania: Does This Baltic Tiger Still Have Teeth? International Business \& Economics Research Journal (IBER), 9(6).

The World Bank (2021). Data Bank. 〈https://data.worldbank.org/indicator/>. 